\title{
STUDY OF TRIPLE VESSEL WAVE PATTERN BY DOPPLER STUDIES IN LOW RISK AND HIGH RISK PREGNANCIES AND PERINATAL OUTCOME
}

\author{
Kondareddy Narasappagari Srilakshmi ${ }^{1}$, Raghavendra² ${ }^{2}$ A. A. Khazi ${ }^{3}$
}

\section{HOW TO CITE THIS ARTICLE:}

Kondareddy Narasappagari Srilakshmi, Raghavendra, A. A. Khazi. "Study of Triple Vessel Wave Pattern by Doppler Studies in low risk and high risk Pregnancies and Perinatal outcome". Journal of Evolution of Medical and Dental Sciences 2014; Vol. 3, Issue 46, September 22; Page: 11160-11165,

DOI: $10.14260 /$ jemds/2014/3455

ABSTRACT: Role of Triple vessel umbilical, middle cerebral and uterine artery wave pattern by color Doppler study in low and high risk pregnancies in relation to perinatal outcome was studied. Fifty (50) patients with gestational age between 31-40 weeks who were diagnosed to have severe preeclampsia, preeclampsia with IUGR were studied and subjected to color Doppler ultrasonography. Findings of Doppler studies were correlated with the adverse perinatal outcomes. Acceptable wave forms were obtained from uterine artery, MCA and UA in all these cases. All the cases were followed up for the perinatal outcome. Cerebro placental ratio had higher sensitivity (95\%) and NPV (85\%) than UAPI (Sensitivity 66.66\%, NPV 79.40\%) and MCA PI (Sensitivity 83.33\%, NPV 77.27\%), UAPI had higher specificity (93.10\%) and PPV (87.5\%) compared to cerebro placental ratio (Specificity 87\%, PPV 88\%) and MCAPI (Specificity 85\%, PPV 89.28\%).

KEYWORDS: High risk pregnancy; severe preeclampsia, IUGR and Triple vessel, Doppler study, perinatal outcome.

INTRODUCTION: Pre-eclampsia is one of the leading causes of maternal and fetal morbidity and mortality. It affects $2-5 \%$ of pregnancies and is principally disease of first term pregnancy. ${ }^{1}$ Pre eclampsia is a specific syndrome characterized by reduced organ perfusion secondary to vasospasm and endothelial pathophysiology. Almost all the morbidity being due to multisystemic manifestations in many organs including brain, liver, kidney and placenta.

IUGR is a common complication of pre-eclampsia and is due failure of normal placental invasion and development. As a result of impaired uteroplacental blood flow manifestations of preeclamsia may be seen in feto placental unit. These include IUGR, oligohydramnios, placental abruption, fetal hypoxia, perinatal death and non-reassuring fetal status found on antepartum fetal surveillance by Doppler ultrasound.2,3

Recent studies indicate that the cerebroplacental ratio of pulsatility index of MCA and UA is the most sensitive Doppler index for predicting perinatal outcome in fetuses with IUGR.4,5 In the majority of the severely growth retarded fetuses, sequential deterioration of arterial and venous Doppler precedes biophysical profile score deterioration. At least one third of fetuses show early signs of circulatory deregulation 1 week before biophysical profile deterioration, and in most cases, Doppler deterioration preceded biophysical profile deterioration by 1 day. ${ }^{6}$ This indicates the significance of Doppler study in these patients for early detection of fetal compromise.

METHODOLOGY: The study was conducted on fifty women with high risk pregnancies with inclusion criteria and fifty women with low risk pregnancies. Singleton pregnancies with history and physical 
findings suggestive of Severe preeclampsia, IUGR (EFW < 10TH percentile for gestational age), Severe preeclampsia plus IUGR.

The pregnancies with Cardiovascular disease, Multiple gestations, Fetuses with congenital anomalies, Renal disease, Essential hypertension prior to pregnancy and other high risk pregnancies conditions were excluded. Doppler US results were analyzed for prediction of perinatal outcome. Pregnancy was considered to have "Adverse outcome" if Birth Weight is less than 10th percentile, Perinatal death, Emergency CS for fetal distress, Low APGAR score (5 min APGAR score-less than7), Admission to NICU for complications of Low Birth Weight.

Pregnancy outcome was considered to be Uneventful or Favorable when the above complications were absent. The outcome for each pregnancy was obtained by examining the labor ward records and neonatal intensive care unit records wherever appropriate. The UA Pulsatility index ratios were considered abnormal if the value was above the 95th percentile values for gestational age. ${ }^{7}$ The MCA pulsatility index was considered abnormal if the value was below the 5th percentile of previously published values for gestational ge22. The MCA/UA PI ratio (cerebroplacental ratio) is considered abnormal when it is less than 1.08 as given by the Gramellini D et al. 8

STATISTICAL ANALYSIS: Statistical analysis was done by using proportions. The sensitivity, specificity, positive predictive value, negative predictive Value and diagnostic accuracy were determined for all Doppler measurements

\begin{tabular}{|c|c|c|}
\hline Gestational age (Wk) & Study Group & Control Group \\
\hline $31-32$ & 9 & 0 \\
\hline $33-34$ & 5 & 1 \\
\hline $35-36$ & 10 & 3 \\
\hline $37-38$ & 19 & 37 \\
\hline $39-40$ & 7 & 9 \\
\hline
\end{tabular}

Table 1: Gestational Age Distribution in study group and control group

\begin{tabular}{|c|c|c|c|}
\hline Amniotic Fluid & Doppler Normal & $\begin{array}{c}\text { Doppler } \\
\text { Abnormal }\end{array}$ & Total \\
\hline Oligo & 2 & 13 & 15 \\
\hline Normal & 17 & 18 & 35 \\
\hline Total & 19 & 31 & 50 \\
\hline
\end{tabular}

$30 \%(n=15)$ had oligohydramnios and 70\% $(n=35)$ had normal amniotic fluid. 
ORIGINAL ARTICLE

\begin{tabular}{|l|c|c|}
\hline Maternal Complications & Number of Cases & Percentage \\
\hline IUGR & 22 & 44 \\
\hline ANAEMIA & 8 & 16 \\
\hline PREVIOUS LSCS & 2 & 4 \\
\hline HELP SYNDROME & 3 & 6 \\
\hline \multicolumn{2}{|c|}{ Table 3: Maternal complications of study group }
\end{tabular}

\begin{tabular}{|l|c|c|}
\hline \multicolumn{1}{|c|}{ Mode of delivery } & Normal Doppler & Abnormal Doppler \\
\hline Elective LSCS & 1 & 0 \\
\hline EmLSCS & 4 & 10 \\
\hline Normal vaginal delivery & 13 & 22 \\
\hline Total & $\mathbf{1 8}$ & $\mathbf{3 2}$ \\
\hline \multicolumn{2}{|c|}{ Table 4: Mode of Delivery } \\
\hline
\end{tabular}

$\chi 2=26.94, \mathrm{DF}=2, \mathrm{P}<0.001$, There was significant association between abnormal Doppler and caesarean section Delivery

\begin{tabular}{|c|c|c|}
\hline $\begin{array}{c}\text { Pregnancy } \\
\text { outcome }\end{array}$ & $\begin{array}{c}\text { No. of } \\
\text { cases }\end{array}$ & Percentage \\
\hline & $\begin{array}{c}\text { Study } \\
\text { group } \\
\text { Control group }\end{array}$ & $\begin{array}{c}\text { Study } \\
\text { group } \\
\text { Control group }\end{array}$ \\
\hline Adverse & 4210 & 8420 \\
\hline Uneventful & 840 & 1680 \\
\hline Total & $\mathbf{5 0 5 0}$ & $\mathbf{1 0 0} \mathbf{1 0 0}$ \\
\hline Table 5: Pregnancy Outcome in the study group
\end{tabular}

$84 \%(n=42)$ fetuses had at least one abnormal outcome and remaining 8 fetuses had normal outcome.

\begin{tabular}{|l|c|c|c|c|}
\hline \multicolumn{1}{|c|}{$\begin{array}{c}\text { Pregnancy } \\
\text { outcome }\end{array}$} & \multicolumn{2}{c|}{$\begin{array}{c}\text { No. of } \\
\text { cases }\end{array}$} & \multicolumn{2}{c|}{ Percentage } \\
\hline & $\begin{array}{c}\text { Study } \\
\text { group }\end{array}$ & $\begin{array}{c}\text { Control } \\
\text { group }\end{array}$ & $\begin{array}{c}\text { Study } \\
\text { group }\end{array}$ & $\begin{array}{c}\text { Control } \\
\text { group }\end{array}$ \\
\hline EmLSCS & 15 & 9 & 30 & 18 \\
\hline Low Apgar Score & 8 & 0 & 16 & 0 \\
\hline NICU Admission & 19 & 0 & 38 & 0 \\
\hline Neonatal Death & 8 & 0 & 16 & 0 \\
\hline Low Birth Weight & 35 & 7 & 70 & 14 \\
\hline Preterm Delivery & 24 & 3 & 48 & 6 \\
\hline
\end{tabular}

Table 6: Adverse outcome Parameters in Study and Control Groups 
$70 \%$ of neonates $(n=35)$ had birth weight of less than $2.5 \mathrm{~kg}$. Of the 50 neonates, 19 neonates were admitted to NICU, 8 neonates had 5 min Apgar score of less than 7 and 15 babies were born by emergency caesarean section for fetal distress.

\begin{tabular}{|c|c|c|c|c|c|c|}
\hline & \multicolumn{2}{|c|}{ Abnormal } & \multicolumn{2}{c|}{ Normal } & \multicolumn{2}{c|}{ Total } \\
\hline & $\begin{array}{c}\text { No. of } \\
\text { cases }\end{array}$ & percentage & $\begin{array}{c}\text { No. of } \\
\text { cases }\end{array}$ & percentage & $\begin{array}{c}\text { No. of } \\
\text { cases }\end{array}$ & percentage \\
\hline $1-1.50$ & 11 & 78.50 & 3 & 21.50 & 14 & 100 \\
\hline $1.51-2$ & 11 & 68.50 & 5 & 31.25 & 16 & 100 \\
\hline $2-2.50$ & 7 & 46.60 & 8 & 53.30 & 15 & 100 \\
\hline $2.50-3$ & 1 & 25 & 3 & 75 & 4 & 100 \\
\hline$>3$ & 0 & 0 & 1 & 100 & 1 & 100 \\
\hline Total & $\mathbf{3 0}$ & $\mathbf{6 0}$ & $\mathbf{2 0}$ & $\mathbf{4 0}$ & $\mathbf{5 0}$ & $\mathbf{1 0 0}$ \\
\hline \multicolumn{7}{|c|}{ Table 7: Birth weight distribution in study group } \\
\hline
\end{tabular}

$\chi 2=25.96, \mathrm{DF}=4, \mathrm{P}<0.001$, Doppler results considered for umbilical and middle cerebra arteries together are significantly associated with birth weight.

DISCUSSION: Umbilical artery and middle cerebral artery Doppler ultrasound clearly depicts the information about placental resistance and the changes in the fetal hemodynamic in response to it. Middle cerebral artery Doppler has enabled the confirmation of brain sparing effect in IUGR. It is possible to use a single cut off value for cerebroplacental ratio after 30thweek because cerebralumbilical Doppler ratio does not vary significantly between 30thand $40^{\text {th }}$ weeks as reported by Waldimir off et $\mathrm{al}^{9}$ who observed a significant differences in cerebroplacental ratio only between weeks 26-38.

After 26thweek, the statistical comparison showed no significant differences between the intervals considered. Arbeille11et al also found the cerebral-placental ratio constant during the pregnancy and suggested 1 as the cut off value and all values below 1 were considered abnormal. We considered the study of Gramellini et al ${ }^{8}$ that cerebroplacental ratio less than 1.08 as abnormal. We have studied about 50 pregnancies with preeclampsia and clinical suspicion of IUGR.

$70 \%$ of neonates $(n=35)$ had birth weight of less than $2.5 \mathrm{~kg}$. Of the 50 neonates, 19 neonates were admitted to NICU, 8 neonates had 5 min Apgar score of less than 7 and 15 babies was born by emergency caesarean section for fetal distress. There were 8 neonatal deaths. Of the 8 neonatal deaths, 1 case had reversal of diastolic flow and 5 had absent diastolic flow.

Out of 50 cases studied, 34 (68\%) showed positive Doppler indices in any of the three vessels studied. The remaining 16 (32\%) cases showed normal Doppler indices in all the three vessels studied. Among abnormal 34 cases, 29 (85 \%) cases, 25 (74\%) cases and 15 (44\%) had abnormal Middle cerebral artery, uterine artery and umbilical artery Doppler indices respectively. Maximum number of abnormal cases $(95.7 \%)$ were induced and delivered.

Babies of 19 cases (55\%) with abnormal Doppler indices had NICU stay whereas 4 babies $(8 \%)$ of the cases with normal Doppler indices had NICU stay? Among abnormal cases, 8 babies (24\%) had APGAR score $<7$ compared to 1 baby (3\%) in normal cases $(\mathrm{p}<0.001)$. $336 \%$ of normal 
cases and $45.5 \%$ of abnormal cases had babies with birth weight in the range of 1.5 to $1.99 \mathrm{Kg} .5$ babies (14\%) of abnormal cases had $<1 \mathrm{~kg}$ birth weight and none of the babies of normal cases had $<1 \mathrm{~kg}$ birth weight.

In 5 patients with AEDV there were 2 still born, 3 neonatal deaths and 1 case with REDF had early neonatal death accounting for $100 \%$ perinatal mortality in both AEDV REDF. Thus triple vessel Doppler study is very useful in predicting high risk pregnancies with adverse perinatal outcome when the Doppler velocimetry is abnormal

\section{BIBLIOGRAPHY:}

1. Aris T. Papageorghious, Christian K H. Yu, II se E. Erasmur, Howard S. Cuckle., Kypros H. Nicolaides, Br. J. Obstet Gynaecol June 2005, vol. 112 pp-707-709.

2. ACOG committee on obstetrics practice ACOG practice bulletin diagnosis and management of pre-eclampsia and eclampsia. Number 33, January 2002, American college of obstetrician and gynecologist, Int. J. Gynaecol 2002; 77; 65-75.

3. Schulman H, Fleiscer a Steen W, Farmakides G. Jagani N. Blattner P Umbilical velocity wave rations in human pregnancy Am J Obstet gynaecol 1984, 148: 985- 90.

4. Arias F. Accuracy of the middle cerebral to umbilical artery resistance index ratios in the prediction of perinatal outcome in patients at high risk for fatal and neonatal complications. Am J Obstet Gynaecol 1994; 171: 1541-1545.

5. Bahado-singh RO, Kovanci E, Jeffres A, Utku OZ, Deren O, copel J et al. The Doppler cerebroplacental ratio and perinatal outcome in intrauterine growth restriction. Am J Obstet Gynaecol 1999; 180: 750-756.

6. Baschat A A, Gem bruch U, Harman C R. The sequence of changes in the Doppler and Biophysical parameters as severe fetal growth restriction worsens. Ultrasound Obstet Gynaecol 2001; 18: 571.

7. Chappel I. Bewley S: Pre-eclamptic Toxemia. The Role of uterine artery Doppler Br. J. Obstet gynaecol 105, 379-382; 1998.

8. Gramellini D, Folli MC, Raboni S, Vadora E, Merialdi A. Cerebral-umbilical Doppler ratio as a predictor of adverse perinatal outcome. Obstet Gyneacol 1992; 74: 416-420.

9. Wald emir off JW, Wijingaard JAGW, Degani S, Noordam MJ, Eyck J, Tonge HM. Cerebral and umbilical arterial blood flow velocity waveforms in normal and growth retarded pregnancies. Obstet Gynaecol 1987; 69: 705-9. 


\section{ORIGINAL ARTICLE}

\section{AUTHORS:}

1. Kondareddy Narasappagari Srilakshmi

2. Raghavendra

3. A. A. Khazi

\section{PARTICULARS OF CONTRIBUTORS:}

1. Assistant Professor, Department of Obstetrics and Gynaecology, Vijayanagar Institute of Medical Sciences, Bellary, Karnataka.

2. Resident Radiologist, Department of Radiagnosis, Vijayanagar Institute of Medical Sciences, Bellary, Karnataka.

3. Former Professor \& HOD, Department of Obstetrics and Gynaecology, Vijayanagar Institute of Medical Sciences, Bellary, Karnataka.

\section{NAME ADDRESS EMAIL ID OF THE} CORRESPONDING AUTHOR:

Dr. Kondareddy Narasarappagari Srilakshmi, $4^{\text {th }}$ Cross, Sonthalinganna Colony, Gandhi Nagar, Bellary.

Email: drsrilakshmi@gmail.com

Date of Submission: 12/09/2014.

Date of Peer Review: 13/09/2014.

Date of Acceptance: 15/09/2014.

Date of Publishing: 19/09/2014. 